\title{
UPAYA PENINGKATAN KINERJA GURU MELALUI TEKNIK LESSON STUDY SECARA KOLABORATIF DAN RUTIN DI TAMAN KANAK- KANAK ISLAM AL AMAL KOTA JAMBI
}

\author{
Siti Chotimah \\ TK Pertiwi II \\ Email: sitichotimah111061@gmail.com
}

\begin{abstract}
Abstrak
Tuntutan masyarakat saat ini adalah pendidikan yang bermutu, sekolah dituntut memperbaiki atau meningkatkan pencitraan publik sehingga masyarakat yakin bahwa sekolah tersebut layak menjadi pilihan putra-putrinya. Lesson study dengan karakteristiknya nampaknya dapat digunakan sebagai salah satu alternatif untuk mengatasi masalah tersebut sehingga pencitraan publik sekolahmeningkat.

Memang Lesson Study banyak menekankan pada pembelajaran di kelas namun dampak kegiatan ini bisa pada aspek yang lain misal: peningkatan sarana pembelajaran, inovasi sekolah, perubahan visi dan misi sekolah, motivasi guru dan pimpinan sekolah, serta muncul aktivitas ekstrakurikuler dan lain-lain. Lesson study berbasis sekolah yang dilakukan secara rutin akan muncul inovasi pada sekolah sehingga dapat digunakan sebagai upaya memperbaiki citra publik sekolah, kegiatan bisa berlangsung dengan baik perlu adanya komitmen kepala sekolah dan kemauan guru unstuck memperbaiki diri.
\end{abstract}

\section{Kata kunci: Kinerja, Guru, Lesson Study}

\section{A. PENDAHULUAN}

\section{Latar Belakang}

Salah satu persoalan pendidikan yang sedang dihadapi bangsa kita adalah persoalan mutu pendidikan pada setiap jenjang dan satuan pendidikan. Berbagai usaha telah dilakukan untuk meningkatkan mutu pendidikan nasional, antara lain melalui berbagai pelatihan dan peningkatan kompetensi guru, pengadaan buku dan alat pelajaran, perbaikan sarana dan prasarana pendidikan, dan meningkatkan mutu manajemen sekolah. Namun demikian, indikator mutu pendidikan belum menunjukkan peningkatan yang berarti. Sebagian sekolah, terutama di kota-kota, menunjukkan peningkatan mutu pendidikan yang cukup menggembirakan, sebagian besar lainnya masih memprihatinkan. Pentingnya meningkatkan mutu setiap sekolah dengan manajemen yang baik dan benar, sehingga dapat mencapai tujuan pendidikan yang tepat.(Sumarto, 2017) 
Dalam upaya meningkatkan mutu harus adanya proses mutu yang di ligitimasi oleh badan akreditasi sesuai dengan ketentuan, (Sumarto, 2018), pemerintah khususnya melalui Departemen Pendidikan Nasional terus menerus berupaya melakukan berbagai perubahan dan pembaharuan sistem pendidikan kita.Salah satu upaya yang sudah dan sedang dilakukan, yaitu berkaitan dengan faktor guru. Lahirnya Undang-Undang No. 14 tahun 2005 tentang Guru dan Dosen dan Peraturan Pemerintah No. 19 Tahun 2005 tentang Standar Nasional Pendidikan, pada dasarnya merupakan kebijakan pemerintah yang di dalamnya memuat usaha pemerintah untuk menata dan memperbaiki mutu guru di Indonesia. Michael G. Fullan yang dikutip oleh Suyanto dan Djihad Hisyam (2000) mengemukakan bahwa "educational change depends on what teachers do and think...". Pendapat tersebut mengisyaratkan bahwa perubahan dan pembaharuan sistem pendidikan sangat bergantung pada "what teachers do and think", atau dengan kata lain bergantung pada penguasaan kompetensi guru. Setiap sekolah yang bermutu harus di buktikan dengan adanya proses akreditasi oleh lembaga akreditasi, sehingga secara legitimasi sekolah tersebut memang di akui memiliki mutu yang baik.(Pohan, 2018)

Jika kita amati lebih jauh tentang realita kompetensi guru saat ini agaknya masih beragam. Sudarwan Danim (2002) mengungkapkan bahwa salah satu ciri krisis pendidikan di Indonesia adalah guru belum mampu menunjukkan kinerja 
(work performance) yang memadai. Hal ini menunjukkan bahwa kinerja guru belum sepenuhnya ditopang oleh derajat penguasaan kompetensi yang memadai, oleh karena itu perlu adanya upaya yang komprehensif guna meningkatkan kompetensi guru.

Berdasarkan masalah di atas, maka berbagai pihak mempertanyakan apa yang salah dalam penyelenggaraan pendidikan kita? Kurangnya pemahaman guru akan tugasnya sebagai agen pembelajaran, merupakan salah satu faktor rendahnya mutu pembelajaran. Guru sebagai agen pembelajaran harus memiliki beberapa kompetensi diantaranya adalah kompetensi kepribadian, kompetensi pedagogik, kompetensi profesional, dan kompetensi sosial. Apabila guru mampu menguasai kompetensi tersebut maka mutu pendidikan akan meningkat.

Dari uraian di atas, penulis selaku kepala sekolah melakukan terobosan untuk menyikapi sekaligus memperbaiki pola-pola pemikiran yang salah dengan memberikan pengarahan/ pembinaan guru berbasis sekolah yang dinamakan dengan (Lesson Study) secara kolaboratif dan berkelanjutan berlandaskan prinsipprinsip kolegalitas dan mutual learning untuk membangun komunitas belajar, untuk membekali guru dalam melaksanakan tugasnya sebagai agen pembelajaran. Kata kuncinya adalah "rutinitas" penulis mempunyai keyakinan bahwa dengan pengarahan secara rutin, terprogram dengan baik dan kontrol terhadap persiapan guru sebelum melaksanakan tugas mengajar di kelas maka akan terbentuk tenaga pendidik yang produktif/ profesional dan mampu meningkatkan mutu pembelajaran. Memang, dalam awal-awal pelaksanaan program ini ada beberapa diantara guru yang menunjukkan sikap acuh tak acuh, tetapi dengan kesabaran dan ketekunan akhirnya guru tersebut sangat antusias setelah merasakan dampak dan manfaat yang dapat dipetik dari pelaksanaan program tersebut.

Hubungan kepala sekolah dengan guru-guru harus baik, tanggung jawab, didasari dengan kejujuran, kesetiaan, keikhlasan dan kerjasama. Apabila diibaratkan dalam satu keluarga, maka hubungan Kepala Sekolah dengan guru- 
guru lainnya harus beriangsung bagaikan hubungan satu saudara dengan saudara lainnya, dan hubungan kepala sekolah dengan siswa harus seperti hubungan ayah dengan anak.

Maka berdasarkan latar belakang tersebut penulis melakukan upaya perbaikan untuk meningkatkan mutu pembelajaran di Sekolah Taman Kanakkanak Islam Al Amal Kota Jambi melalui Penelitian Tindakan Sekolah (PTS) dengan judul: "Upaya Peningkatan Kinerja Guru Melalui Teknik Lesson Study Secara Kolaboratif dan Rutin Di Taman Kanak-kanak Islam Al Amal Kota Jambi”.

\section{Rumusan Masalah}

Dalam Penelitian Tindakan Sekolah ini penulis merumuskan masalah sebagai berikut:

1) Bagaimana perencanaan guru dalam melaksanakan tugas mengajar agar mutu pembelajaran meningkat?

2) Bagaimana pemahaman guru terhadap tugasnya sebagai agen pembelajaran?

3) Bagaimana guru menerapkan teknik praktek rencana pembelajaran di kelas untuk meningkatkan mutu pembelajaran?

4) Apakah tingkat kesadaran dan tanggung jawab guru sebagai pendidik sudah seimbang dengan tugas pokok dan fungsi yang dibebankan oleh pemerintah?

\section{Tujuan Penelitian}

Secara khusus tujuan penelitian ini adalah untuk meningkatkan kesadaran dan tanggung jawab guru akan tugas pokok dan fungsinya yang dibebankan oleh orang tua, masyarakat dan pemerintah.

\section{Manfaat Penelitian}

\section{1) Bagi Guru}

Mengembangkan keahlian guru dalam mengajar, baik pada saat merencanakan maupun selama berlangsungnya kegiatan pembelajaran.

\section{2) Manfaat bagi Sekolah}


Penelitian ini diharapkan dapat memberikan umpan balik bagi pembinaan dan pengembangan kompetensi guru untuk meningkatkan mutu pembelajaran dan pendidikan.

\section{3) Manfaat Bagi Siswa}

Siswa akan menikmati pembelajaran yang lebih tertib dan bermutu karena guru telah mempersiapkan segala sesuatunya dengan baik.

\section{B. KAJIAN PUSTAKA}

\section{Kinerja Guru}

Kinerja adalah hasil kerja secara kualitas dan kuantitas yang dicapai oleh seorang pegawai dalam melaksanakan tugasnya sesuai dengan tanggung jawab yang diberikan kepadanya.Malayu Hasibuan mengungkapkan bahwa kinerja atau potensi kerja adalah suatu hasil kerja yang dicapai seseorang dalam melaksanakan tugas-tugas yang diberikan kepadanya yang didasarkan atas kecakapan, pengalaman, dan kesungguhan serat waktu. ${ }^{1}$

Berkenaan dengan kinerja guru, UU Republik Indonesia No. 20 Tahun 2003 tentang Sisdiknas Pasal 39 ayat (2), menyatakan bahwa pendidik merupakan tenaga profesional yang bertugas merencanakan dan melaksanakan proses pembelajaran, menilai hasil pembelajaran, melakukan pembimbingan dan pelatihan serta melakukan penelitian dan pengabdian kepada masyarakat, terutama bagi pendidik pada perguruan tinggi. ${ }^{2}$

Burhanudin, mengemukakan bahwa kinerja guru adalah gambaran kualitas kerja yang dimiliki guru dan termanifestasi melalui penguasaan dan aplikasi atas kompetensi guru. ${ }^{3}$ Pandangan ini menunjukan bahwa kinerja pada dasarnya merupakan gambaran dari penguasaan dan aplikasi terhadap kompetensi guru dalam mengaktualisasikan tugas dan perannya sebagai guru.

\footnotetext{
${ }^{1}$ Malayu, S.P. Hasibuan, Manajemen Sumber Daya Manusia.(Jakarta: PT. Bumi Aksara 2007), hal.94.

${ }^{2}$ Sekretariat Negara RI, Undang -Undang Republik Indonesia Nomor 20 Tahun 2003 tentang Sistem Pendidikan Nasional, Sekratariat Negara RI, Jakarta, 2003, hal. 15.

${ }^{3}$ Burhanudin, Analisis Administrasi Manajemen dan Kepemimpinan Pendidikan.(Jakarta: Bumi aksara, 2007), hal. 1.
} 
Depdiknas menyatakan kinerja guru adalah kemampuan guru untuk mendemonstrasikan berbagai kecakapan dan kompetensi yang dimilikinya. Esensi dari kinerja guru tidak lain merupakan kemampuan guru dalam menunjukkan kecakapan atau kompetensi yang dimilikinya dalam dunia kerja yang sebenarnya.Wagiran dalam Jurnal Pendidikan Evaluasi Pendidikan Tahun 17 Nomor 1 mendefinisikan kinerja (performance) guru adalah hasil yang dicapai oleh guru dalam melaksanakan tugas-tugas yang dibebankan kepadanya yang didasarkan atas kecakapan, pengalaman dan kesungguhan serta waktu dengan output yang dihasilkan tercermin dari kuantitas maupun kualitasnya.

Berdasarkan berbagai pengertian di atas, maka dapat disimpulkan bahwa kinerja guru merupakan hasil pekerjaan atau prestasi kerja yang dilakukan oleh seorang guru berdasarkan kemampuan mengelola kegiatan belajar mengajar, yang meliputi perencanaan pembelajaran, pelaksanaan pembelajaran, evaluasi pembelajaran dan membina hubungan antar pribadi (interpersonal) dengan siswanya.

Menurut Mulyasa, faktor-faktor yang dapat meningkatkan kinerja guru, yaitu: ${ }^{4}$

a. Dorongan untuk bekerja.

Bilamana seorang guru merasa bahwa minat atau perhatiannya seusai dengan jenis dan sifat pekerjaan yang dilakukan maka guru tersebut akan memiliki dorongan untuk kerja yang tinggi.

b. Tanggung jawab terhadap tugas.

Seseorang yang bertanggung jawab selalu memberikan yang terbaik dari apa yang dikerjakannya. Bekerja dengan penuh tanggung jawab berarti memperhatikan hal-hal yang kecil yang dapat membuat perbedaan dari hasil yang dikerjakan. Guru memiliki tugas dan tanggung jawab dalam meningkatkan pendidikan di sekolah. Guru dapat berperan serta dalam melaksanakan kegiatan di sekolah. Karena dengan adanya peran serta dari guru maka kegiatan sekolah dapat berjalan dengan lancar.

${ }^{4}$ E.Mulyasa, Standar Kompetensi dan Sertifikasi Guru,(Bandung: Remaja Rosdakarya, 2007), hal. 227 
c. Minat terhadap tugas.

Minat merupakan rasa ketertarikan seorang guru untuk melakukan suatu hal yang diikuti oleh rasa senang sehingga akan menghasilkan kepuasan terhadap hasil yang dicapai. Semakin tinggi minat yang dimiliki seorang guru dalam menjalankan tugas, semakin tinggi pula hasil yang dicapainya.Minat terhadap tugas merupakan rangkaian yang ada pada setiap guru dan minat itu hampir bisa dipastikan sebagai suatu kebutuhan.

d. Penghargaan terhadap tugas.

Agar seorang guru dapat melaksanakan tugas-tugasnya dengan baik, penuh semangat dan disiplin yang tinggi sesuai tuntutan kerja, maka perlu diberikan berbagai dukungan penghargaan, terutama penghargaan yang dapat menunjang dan mempermudah dalam melaksanakan tugas-tugasnya. Bentuk dan jenis penghargaan yang perlu diberikan, antara lain peningkatan kesejahteraan, khususnya penyediaan kebutuhan fisik (sandang, pangan, dan papan); peningkatan profesionalisme; peningkatan kualitas keimanan dan ketaqwaan terhadap Tuhan Yang Maha Esa; memberikan perlindungan hukum dan rasa aman; peningkatan jenjang karir yang jelas; pemberian kebebasan dalam pengembangan karier dan dalam pelaksanaan tugas-tugasnya; pemberian kemudahan dalam menjalankan tugas.

e. Peluang untuk berkembang.

Hal ini terkait dengan keberanian guru untuk bertindak sebagai pengemban program, untuk memasukkan bahan-bahan yang bersumber dari kehidupan sosial budaya di lingkungan sekolah dimana mereka berada. Hal ini dapat dilakukan apabila tercipta harmonisasi nilai orientasi pada tujuan dengan nilai orientasi pada proses belajar. Oleh karena itu pembinaan profesionalisme guru perlu dilakukan secara kontinyu dan berkesinambungan, disamping itu penghargaan terhadap kinerja guru harus diimbangi dengan pengembangan kesejahteraan guru.

f. Perhatian dari kepala sekolah.

Kemampuan manajerial kepala sekolah akan mempunyai peranan dalam meningkatkan kinerja guru. Sekolah sebagai lembaga pendidikan formal 
merupakan suatu pola kerjasama antara manusia yang saling melibatkan diri dalam satu unit kerja (kelembagaan). Dalam proses mencapai tujuan pendidikan, tidak bisa terlepas dari perhatian kepala sekolah terhadap warga sekolah agar tujuan pendidikan yang telah digariskan dapat tercapai.

g. Hubungan interpersonal dengan sesama guru.

Seorang guru memang harus memiliki kemampuan berkomunikasi dengan baik dan dalam hal ini kemampuan komunikasi interpersonal perlu dimiliki oleh seorang guru karena ini adalah faktor utama yang berdampak pada keaktifan peserta didik dalam mengikuti proses belajar mengajar.

h. MGMP dan KKG.

Kegiatan MGMP dan KKG, sebagai organisasi atau forum musyawarah guru mata pelajaran, yang dilaksanakan setiap bulan sekali dimana guru mata pelajaran aktif dalam kegiatan bersama, mempunyai network lokal, nasional dan internasional yang kuat.Mempunyai metode implementasi ide yang efektif, mengembangkan citra guru, mengembangkan kurikulum yang sesuai dengan tuntutan zaman. Dalam kegiatan MGMP dan KKG, guru diharapkan mampu mengekspresikan pemikirannya, guru mempunyai kepribadian proaktif untuk meningkatkan kemampuannya dalam mengajar dan berkreasi dengan siswa

i. Kelompok diskusi terbimbing.

Dalam kelompok diskusi terbimbing akan terlihat adanya proses interaksi antara dua atau lebih individu yang terlibat saling tukar menukar pengalaman, maupun informasi, untuk memecahkan suatu masalah. Dalam kelompok diskusi terbimbing ini diharapkan dapat mempertinggi partisipasi guru secara individual dan mengembangkan rasa sosial antar sesama guru.

j. Layanan perpustakaan.

Perpustakaan berfungsi sebagai salah satu faktor yang mempercepat akselerasi transfer ilmu pengetahuan, oleh karena itu perpustakaan merupakan suatu kesatuan yang tidak dapat dipisahkan dalam sistem pendidikan suatu lembaga.

\section{Lesson Study}

Lesson study merupakan terjemahan langsung dari bahasa Jepang jugyokenkyu, yang berasal dari dua kata jugyo = lesson atau pembelajaran dan 
kenkyu = study atau pengkajian.Berdasarkan terjemahan tersebut, lesson study adalah pengkajian atau penelitian tentang pembelajaran. Menurut Lewis, lesson study adalah salah satu bentuk kegiatan pengembangan profesional guru dengan ciri guru membuka pelajaran dan guru sejawat lain sebagai observer, sehingga memungkinkan guru-guru dapat membagi pengalaman pembelajaran dengan sejawatnya. ${ }^{5}$

Menurut Cerbin dan Kopp, lesson study merupakan proses pengembangan kompetensi profesional untuk para guru yang berasal dan dikembangkan secara sistematis dalam sistem pendidikan di Jepang dengan tujuan utama menjadikan proses pembelajaran menjadi lebih baik dan efektif. ${ }^{6}$ Menurut Styler dan Hiebert, lesson study merupakan suatu proses kolaboratif pada sekelompok guru ketika mengidentifikasi masalah pembelajaran, merancang suatu skenario pembelajaran (yang meliputi kegiatan mencari buku dan artikel mengenai topik yang akan dibelajarkan), membelajarkan peserta didik sesuai skenario (salah seorang guru melaksanakan pembelajaran sementara yang lain mengamati), mengevaluasi dan merevisi skenario pembelajaran, membelajarkan lagi skenario pembelajaran yang telah direvisi, mengevaluasi lagi pembelajaran dan membagikan hasilnya dengan guru-guru lain. ${ }^{7}$

Menurut Walker, lesson study merupakan suatu kegiatan pengkajian terhadap proses pembelajaran di kelas nyata yang dilakukan oleh sekelompok guru secara berkolaborasi dalam jangka waktu lama dan terus menerus untuk meningkatkan keprofesionalannya.

Sedangkan menurut Riandi (Counterpart IMSTEP-JICA), lesson study adalah model pembinaan profesionalisme guru melalui semangat kesejawatan (collegiality) yang secara bersama-sama berusaha meningkatkan kualitas pembelajaran. ${ }^{8}$ Menurut Makoto Yoshida (1999) menyatakan bahwa lesson study

\footnotetext{
${ }^{5}$ Heru Nurcahyo. Improving Biological Science Teacher Competencies Through Applying Lesson Study. (Yogyakarta : Universitas Negeri Yogyakarta), hal.8

${ }^{6}$ Lewis, Lesson Study: A Handbook of Teacher-Led Intructional, (Philadelphia, PA:Research for Better Schools, 2002), hal. 23

7 Muchtar A. Karim, Apa, Mengapa, Dan Bagaimana Lesson Study, (Malang: Fakultas Matematika Dan Ilmu Pengetahuan Alam Universitas Negeri Malang, 2006), 4

${ }^{8}$ Riandi, Peningkatan Profesionalisme Guru,Bandung: Universitas Pendidikan Indonesia
} 
adalah sebuah studi kasus tentang pendekatan orang jepang untuk meningkatkan pengajaran melalui pengembangan guru berbasis sekolah.

Berdasarkan beberapa pengertian tersebut, dapat disimpulkan bahwa lesson study adalah suatu kegiatan untuk pembinaan profesionalisme guru bersama rekan sejawatnya (collegiality) untuk meningkatkan kualitas pembelajaran.

\section{Lesson Study Dalam Kegiatan Pembelajaran}

Lesson Study merupakan model pembinaan profesi pendidik melalui pengkajian pembelajaran secara kolaboratif dan berkelanjutan berlandaskan prinsip-prinsip kolegalitas dan mutual learning untuk membangun komunitas belajar. Lesson Study adalah program yang diterapkan oleh SISTTEMS, (Strengthening In-Service Teacher Training of Mathematics and Science Education at Junior Secondary Level) yaitu bentuk kerjasama antara JICA (Japan International Cooperation Agency) dan MONE / Depdiknas (Ministry of National Education / Departemen Pendidikan Nasional) Indonesia.

Lesson Study bukan merupakan metoda atau strategi pembelajaran tetapi kegiatan yang dapat menerapkan berbagai metoda dan strategi pembelajaran yang sesuai dengan situasi, kondisi, kemampuan komunitas pembelajaran serta berbagai permasalahan yang dihadapi dalam kegiatan pembelajaran.Lesson Study adalah metode yang berorientasi pada praktek untuk meningkatkan keterampilan mengajar oleh guru-guru itu sendiri.

\section{METODE PENELITIAN}

\section{Setting Penelitian}

Penelitian ini dilaksanakan diTaman kanak-kanak (TK) Islam Al Amal yang beralamatkan di J1. H. Kasim Alamlah RT. 17 No. 03 Kel. Pematang Sulur Kec. Telanai Pura Kota Jambi.

\section{Subjek Penelitian}

Yang menjadi subjek penelitian adalah guru-guru di TK Islam Al Amal kota Jambi. 


\section{Prosedur Penelitian}

\section{- Perencanaan Tindakan}

Perencanaan Tindakan Sekolah dilakukan dengan penilaian terlebih dahulu terhadap kebutuhan-kebutuhan guru yang diperoleh dari informasi hasil pembicaraan dengan guru.Diperoleh kesimpulan bahwa guru memiliki keterbatasan dalam menyusun RPP.Permasalahan ini diangkat menjadi isu pembinaan dengan memberikan penyuluhan tentang penyusunan RPP.

Sebagai langkah pertama adalah melakukan penilaian terhadap RPP yang disusun oleh guru dengan menggunakan instrumen penilaian RPP. Teknik dan alat pengumpul data adalah menggunakan teknik observasi atau pengamatan terhadap dokumentasi perangkat pembelajaran guru (RPP) dan eksen pembelajarannya di kelas dengan menggunakan instrumen

\section{- Pelaksanaan Tindakan}

Setelah dilakukan penilaian terhadap RPP, dilakukan penyuluhan penyusunan RPP sesuai pedoman.

\section{Observasi/Pengamatan}

RPP yang sudah disusun dilaksanakan dikelas dengan menggunakan instrumen.

\section{Refleksi}

Tindakan-tindakan tersebut diimplementasikan dalam tiga siklus tindakan dan setiap siklus diakhiri dengan refleksi.Siklus pertama penilaian RPP menghasilkan penilaian perlunya diberi penyuluhan penyusunan RPP.Siklus kedua yaitu melakukan pembinaan melalui tekhnik Lesson Study dan siklus ketiga menghasilkan pembicaraan lebih lanjut tentang supervisi akademik (pembuatan RPP).

\section{PEMBAHASAN PENELITIAN}

\section{- Deskripsi Pra Siklus}

Kondisi awal sebelum diterapkan metode Lesson Study secara rutin sebelum guru melakukan tugas mengajar menunjukkan: 
1. Kurangnya kesadaran dan tanggung jawab guru akan tugas pokok dan fungsi yang dibebankan oleh pemerintah.

2. Kurangnya perencanaan yang matang dalam melaksanakan tugas dan belum siapnya guru untuk mengadakan perubahan kearah yang lebih maju sesuai dengan perkembangan dunia pendidikan.

3. Kurangnya pemahaman guru akan tugasnya sebagai agen pembelajaran.

4. Belum terbentuknya disiplin sekolah dan iklim budaya kerja sekolah yang mengacu pada peningkatan mutu pembelajaran.

Pemahaman guru terhadap tugas sebelum diterapkannya pendekatan tersebut adalah dalam melaksanakan tugasnya hanya mengandalkan persiapan seadanya bahkan kadang sama sekali tidak ada persiapan. Hal ini terjadi karena fungsi kontrol sebagai salah satu tugas kepala sekolah tidak berjalan sebagaimana mestinya.Disamping itu seolah-olah guru hanya sekedar melaksanakan tugas tanpa ada perancanaan yang matang dan tidak berpikir bagaimana hasil akhir setelah melaksanakan tugas mengajar.

Strategi melaksanakan lesson study berdasarkan hasil penelitian penulis:

\section{a. Perencanaan (Plan)}

\section{Identifikasi Masalah Pembelajaran}

- Materi Ajar

1) Kedalaman materi

2) Kesesuaian dengan tuntutan kurikulum

3) Tingkat kesulitan

- Strategi Pembelajaran

a. Pendahuluan

Memotivai siswa belajar

b. Kegiatan inti

1) aktivitas belajar yang diharapkan

2) rancangan interaksi siswa dengan bahan ajar

3) rancangan interaksi siswa dengan siswa

4) rancangan interaksi siswa dengan guru

a. Penutup 
Aktivitas siswa yang diharapkan untuk menyimpulkan pelajaran

\section{- Mempersiapkan Perangkat Pembelajaran}

1. Silabus

2. Rencana Pelaksanaan Pembelajaran

3. Lembar Kegiatan Siswa

4. Alat tes

\section{- Menentukan Observer}

1. Kepala Sekolah

2. Guru

3. Pengawas Sekolah

- Menentukan Guru Model (pelaksana pembelajaran di kelas)

\section{c. Pelaksanaan (Do)}

a. Pertemuan singkat (briefing) dipimpin fasilitator (kepala sekolah).

b. Guru model mengemukakan rencana singkat (rencana pembelajaran, tujuan, kedudukan materi ajar dalam kurikulum, perkiraan kemungkinan respon siswa).

c. Kepala sekolah mengingatkan observer untuk tidak mengintervensi proses belajar mengajar.

d. Observer dipersilahkan memilih tempat strategis sesuai rencana pengamatan.

e. Guru model melaksanakan proses belajar mengajar.

Pedoman observer:

a. Kejelasan tujuan pembelajaran.

b. Aktivitas mengarah ke pencapaian tujuan.

c. Langkah-langkah pembelajaran berkaitan mendukung pemahaman siswa.

d. Media pembelajaran mendukung pencapaian tujuan.

e. Diskusi kelas membantu pemahaman konsep.

f. Materi ajar sesuai tingkat kemampuan siswa.

g. Penggunaan pengetahuan awal untuk mendukung pemahaman konsep. 
h. Pertanyaan guru mendorong dan memfasilitasi cara berpikir siswa.

i. Pemberian penghargaan gagasan siswa.

j. Kesimpulan didasarkan pendapat siswa.

k. Kesimpulan sesuai tujuan.

1. Pemberian penguatan.

\section{- Refleksi (See)}

a. Menentukan fasilitator.

b. Fasilitator mengenalkan observer dengan spesifikasi bidang ilmu.

c. Fasilitator menyampaikan agenda refleksi.

d. Fasilitator menyampaikan aturan main.

e. Guru model menyampaikan

f. Team pengembang memberi komentar.

g. Fasilitator memberi kesempatan observer berkomentar

h. Fasilitator mempersilahkan tenaga ahli merangkum diskusi.

i. Fasilitator mengucapkan terimakasih dan mengumumkan kegiatan lesson study berikutnya.

\section{E. KESIMPULAN DAN SARAN}

\section{Kesimpulan}

Berdasarkan pembahasan hasil penelitian yang telah dilakukan dalam bab sebelumnya melalui "Upaya Peningkatan Kinerja Guru Melalui Teknik Lesson Study Secara Kolaboratif dan Rutin Di Taman Kanak-kanak Islam Al Amal dapat ditarik kesimpulan, sebagai berikut:

- Pelaksanaan program yang rutin dan berkesinambungan merupakan kunci keberhasilan dalam melaksanakan tugas sebagai kepala sekolah dalam meningkatkan mutu pembelajaran di kelas.

- Pada "Upaya Peningkatan Kinerja Guru Melalui Teknik Lesson Study Secara Kolaboratif dan Rutin Di Taman Kanak-kanak Islam A Amal Kota Jambi mampu membentuk tenaga pendidik yang produktif/profesional dan mampu meningkatkan mutu pembelajaran. 
- Dengan adanya terobosan dan inovasi melalui pendekatan "Upaya Peningkatan Kinerja Guru Melalui Teknik Lesson Study Secara Kolaboratif dan Rutin Di Taman Kanak-kanak Islam Al Amal" ada pengaruh yang besar terhadap hasil belajar siswa.

Dengan demikian "Upaya Peningkatan Kinerja Guru Melalui Teknik Lesson Study Secara Kolaboratif dan Rutin Di Taman Kanak-kanak Islam Al Amal Kota Jambi" dapat meningkatkan mutu pembelajaran di kelas.

\section{Saran}

Berdasarkan kesimpulan di atas, guru dituntut untuk melaksanakan beberapa hal dalam meningkatkan kualitas pembelajaran, khususnya dalam meningkatan penguasaan materi pelajaran dan keaktifan siswa dalam belajar.Adapun hal-hal yang harus dilakukan guru diantaranya: Menentukan tujuan pembelajaran (lesson) satuan (unit) pelajaran, dan mata pelajaran yang efektif. Mengkaji dan meningkatkan pelajaran yang bermanfaat bagi siswa.Memperdalam pengetahuan tentang mata pelajaran yang disajikan para guru. Menentukan tujuan jangka panjang yang akan dicapai para siswa. Menentukan pelajaran secara kolaboratif.Mengkaji secara teliti belajar dan perilaku siswa.Mengembangkan pengetahuan pembelajaran yang dapat diandalkan.Melakukan refleksi terhadap pengajaran yang dilaksanakannya berdasarkan pandangan siswa dan koleganya.

Disamping itu, pengalaman dalam pelaksanaan penelitian tindakan sekolah (PTS) perlu adanya kelompok kerja antara guru, untuk saling tukar pikiran dan pengalaman, serta saling membantu dalam memecahkan masalah yang dihadapi sehari-hari dalam tugas yang diemban dalam mengajar.

\section{DAFTAR PUSTAKA}

Burhanudin, Analisis Administrasi Manajemen dan Kepemimpinan Pendidikan. Jakarta: Bumi aksara, 2007.

E. Mulyasa, Standar Kompetensi dan Sertifikasi Guru, Bandung: Remaja Rosdakarya, 2007. 
Hari Sudrajat, Manajemen Peningkatan mutu Berbasis Sekolah, Bandung: Cipta Cekas Grafika, 2004.

Heru Nurcahyo. Improving Biological Science Teacher Competencies Through Applying Lesson Study. Yogyakarta : Universitas Negeri Yogyakarta

Lewis, Lesson Study: A Handbook of Teacher-Led Intructional, Philadelphia, PA:Research for Better Schools, 2002

Malayu, S.P. Hasibuan, Manajemen Sumber Daya Manusia. Jakarta: PT. Bumi Aksara 2007.

Mohamad Surya, Psikologi Pembelajaran dan Pengajaran, Bandung: Pustaka Bany Quraisy, 2004

Muchtar A. Karim, Apa, Mengapa, Dan Bagaimana Lesson Study, Malang: Fakultas Matematika Dan Ilmu Pengetahuan Alam Universitas Negeri Malang, 2006

R.L. Mathis \& J.H. Jackson, Human Resource Management: Manajemen Sumber Daya Manusia, Terjemahan Dian Angelia, Jakarta: Salemba Empat, 2006

Prim Masrokan Mutohar, Manajemen Mutu Pendidikan, (Jogjakarta: Ar-Ruz, 2013

Riandi, Peningkatan Profesionalisme Guru, Bandung: Universitas Pendidikan Indonesia

Sekretariat Negara RI, Undang -Undang Republik Indonesia Nomor 20 Tahun 2003 tentang Sistem Pendidikan Nasional, Sekratariat Negara RI, Jakarta, 2003.

Wahjosumidjo, Kepemimpinan Kepala Sekolah (tinjauan teoritik dan permasalahanya), Jakarta: Raja Grafindo persada, 2005.

Rika Ariyani, Editor Jurnal Literasiologi. Literasi Kita Indonesia. STAI Syekh Maulana Qori. Merangin Bangko.

Pohan, S. (2018). Manajemen Sekolah: Wujudkan Guru Profesional. Tarbawi :

Jurnal Ilmu Pendidikan, 14(2), 51-62.

https://doi.org/10.32939/tarbawi.v14i2.265

Sumarto, S. (2017). Equalization and Standardization of Management of Education in Madrasah. HUNAFA: Jurnal Studia Islamika, 14(1), 117-139. https://doi.org/10.24239/jsi.v14i1.450.117-139

Sumarto, S. (2018). Peran Dan Kredibilitas Badan Akreditasi Nasional Sekolah/Madrasah (Ban S/M) Mewujudkan Sekolah Efektif Melalui Manajemen Mutu. Jurnal Literasiologi, 1(1), 12-12. 